\title{
Levels of physical activity and predictors of mortality in COPD*
}

\author{
Níveis de atividade física e preditores de mortalidade na DPOC
}

\author{
Samantha Maria Nyssen, Júlia Gianjoppe dos Santos, Marina Sallum Barusso, \\ Antônio Delfino de Oliveira Junior, Valéria Amorim Pires Di Lorenzo, \\ Mauricio Jamami
}

\begin{abstract}
Objective: To compare the Body mass index, airway Obstruction, Dyspnea, and Exercise capacity (BODE) index scores and its individual components between COPD patients with and without severe physical inactivity, as well as to correlate the number of steps/day with scores of physical activity questionnaires, age, and the BODE index (including its components). Methods: We included 30 patients, who were evaluated for body composition, pulmonary function (FEV $)_{1}$ ), perception of dyspnea (modified Medical Research Council scale), and exercise capacity (six-minute walk distance [6MWD]). The patients also completed the International Physical Activity Questionnaire (IPAQ), short version, and the modified Baecke questionnaire (mBQ). The level of physical activity was assessed by the number of steps/day (as determined by pedometer), using the cut-off of 4,580 steps/day to form two groups: no severe physical inactivity (SPI-) and severe physical inactivity (SPI+). We used the Mann-Whitney test or t-test, as well as Pearson's or Spearman's correlation tests, in the statistical analysis. Results: In comparison with the SPl- group, the SPl+ group showed more advanced age, higher mBQ scores (leisure domain), lower 6MWD (in $\mathrm{m}$ and \% of predicted), and lower IPAQ scores (metabolic equivalent-walk/ week domain and total). The IPAQ scores showed weak correlations with steps/day $(r=0.399)$, age $(r=-0.459)$, and 6MWD-in $\mathrm{m}(\mathrm{r}=0.446)$ and in $\%$ of predicted $(r=0.422)$. Conclusions: In our sample, the cut-off of 4,580 steps/day was not sensitive enough to identify differences between the groups when compared with the predictors of mortality. The IPAQ, short version score correlated with steps/day.
\end{abstract}

Keywords: Pulmonary disease, chronic obstructive/mortality; Pulmonary disease, chronic obstructive/ prevention and control; Motor activity.

\section{Resumo}

Objetivo: Comparar a pontuação do índice Body mass index, airway Obstruction, Dyspnea, and Exercise capacity (BODE) e seus componentes individuais em pacientes com DPOC com grave inatividade física ou não, assim como correlacionar o número de passos diários com pontuações de questionários de atividade física, idade, índice BODE e seus componentes. Métodos: Foram incluídos 30 pacientes, os quais foram avaliados quanto a sua composição corporal, função pulmonar ( $\mathrm{VEF}_{1}$ ), percepção de dispneia (escala modified Medical Research Council) e capacidade de exercício distância percorrida no teste de caminhada de seis minutos (DTC6). Além disso, os participantes responderam ao International Physical Activity Questionnaire (IPAQ) versão curta e questionário de Baecke modificado (QBm). 0 nível de atividade desses pacientes foi avaliado pelo número de passos diários por pedômetro, utilizando-se o ponto de corte de 4.580 passos para a formação de dois grupos: grupo sem grave inatividade física $(\mathrm{GlF}-)$ e grupo com grave inatividade física $(\mathrm{GlF}+)$. Foram utilizados os testes de Mann-Whitney ou t não pareado, assim como os testes de correlação de Spearman ou de Pearson, na análise estatística. Resultados: Idade mais avançada, maiores escores no QBm (domínio lazer), menor DTC6 (em $\mathrm{m}$ e em \% do previsto) e menores escores no IPAQ (domínios equivalentes metabólicos em caminhada e total por semana) foram encontrados no grupo GlF+ do que no grupo GlF-. Houve correlações fracas dos escores do IPAQ com o número de passos diários $(r=0,399)$, idade $(r=-0,459)$, DTC6 em $\mathrm{m}(\mathrm{r}=0,446)$ e em \% do previsto $(r=0,422)$. Conclusões: Na amostra estudada, o ponto de corte de 4.580 passos diários não foi sensível para identificar diferenças entre os grupos estudados quando comparado com os preditores de mortalidade. 0 questionário IPAQ versão curta correlacionou-se com o número de passos diários.

Descritores: Doença pulmonar obstrutiva crônica/mortalidade; Doença pulmonar obstrutiva crônica/ prevenção e controle; Atividade motora.

\footnotetext{
*Study carried out in the Laboratory of Spirometry and Respiratory Therapy, Department of Physical Therapy, Universidade Federal de São Carlos - UFSCar, Federal University of São Carlos - São Carlos, Brazil.

Correspondence to: Samantha Maria Nyssen. Laboratório de Espirometria e Fisioterapia Respiratória, Rodovia Washington Luiz, km 235, CEP 13565-905, São Carlos, SP, Brasil.

Tel. 5516 3351-8343. E-mail: samantha_fisioterapia@hotmail.com

Financial support: None.
}

Submitted: 10 January 2013. Accepted, after review: 4 October 2013. 


\section{Introduction}

Currently, COPD is considered the leading cause of morbidity and the fourth leading cause of mortality worldwide. ${ }^{(1)}$ Its prevalence has been increasing substantially because of the aging of the population, and it is estimated that, in 2020, COPD will be the third most common cause of death in the world..$^{(2)}$

In addition to pulmonary involvement, which leads to airflow limitation that is not fully reversible and dyspnea, ${ }^{(3)}$ COPD is characterized by extrapulmonary impairment, such as skeletal muscle dysfunction, which is related to decreased exercise capacity, which, together with dyspnea, leads to physical inactivity in these patients, establishing a vicious cycle or downward spiral.(4)

Because COPD is multisystemic in nature, with various factors contributing to the severity of the condition, the risk of mortality in patients with COPD began to be evaluated not only by using the Global Initiative for Chronic Obstructive Lung Disease staging system, which is based on the degree of obstruction $\left(\mathrm{FEV}_{1}\right),{ }^{(3)}$ but also by using the Body mass index, airway Obstruction, Dyspnea, and Exercise capacity (BODE) index. The BODE index is a multi-grading system consisting of the

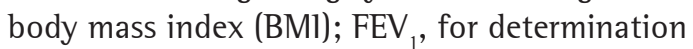
of the degree of airway obstruction; the modified Medical Research Council (mMRC) scale, for assessment of the degree of dyspnea; and the six-minute walk test (6MWT), for assessment of exercise capacity. The BODE index is considered a better predictor of mortality. ${ }^{(5)}$

However, physical inactivity in patients with COPD has now been implicated as a factor directly related to an increased risk of exacerbations and as the best predictor of early mortality in COPD. ${ }^{(6-8)}$ A prospective observational study ${ }^{(8)}$ involving 169 patients with COPD showed that four-year mortality was strongly associated with a physical activity level (PAL) $<1.4$ in these patients. The PAL is an index calculated by dividing total daily energy expenditure (kcal/day) by resting energy expenditure. ${ }^{(8,9)}$

In a recent study, pedometers were considered the most feasible way to monitor physical activity in clinical practice. ${ }^{(10)}$ In addition to being objective, they may serve as a surrogate for higher-cost options, such as accelerometers, and for questionnaires for physical activity assessment, such as the International Physical Activity Questionnaire (IPAQ), ${ }^{(11)}$ short version, and the modified Baecke questionnaire, ${ }^{(12,13)}$ both of which have been translated and validated for use in Brazil; however, these questionnaires are considered inaccurate, especially when administered to older populations. ${ }^{(14)}$

An association had yet to be established between a given number of steps/day and a PAL value of 1.40 (related to marked physical inactivity) in patients with $\mathrm{COPD}^{(8)}$; however, in a study published by Depew et al., ${ }^{(10)}$ this value was associated with a minimum number of 4,580 steps/day, i.e., lower numbers than that correspond to COPD patients with severe physical inactivity and, consequently, at increased risk of early mortality.

Therefore the primary objective of the present study was to compare the scores on the BODE index, which is a predictor of mortality, in patients with COPD divided into two groups: those who achieved the recommended minimal number of 4,580 steps/day and those who did not achieve this value. The secondary objective of the study was to correlate pedometer-determined steps/ day with age, the BODE index (including its individual components), and scores of instruments that assess the level of physical activity in these patients.

The present study tested the hypothesis that patients who do not achieve the minimum recommended number of steps/day have higher scores on the BODE index, i.e., shorter six-minute walk distances (6MWDs), higher BMl values, a greater degree of pulmonary obstruction, and a stronger sensation of dyspnea during daily activities, reflecting a poorer prognosis.

\section{Methods}

This was a cross-sectional study involving 38 participants recruited from a convenience sample of male and female COPD patients with moderate to very severe obstruction $\left(\mathrm{FEV}_{1} / \mathrm{FVC}<70 \%\right.$ and $\mathrm{FEV}_{1}<80 \%$ of predicted), ${ }^{(3)}$ as diagnosed by spirometry, which had been requested by the attending pulmonologist. The patients included in the study were former smokers or nonsmokers, were oxygen-dependent or non-oxygen-dependent, and had been clinically stable in the two months prior to the study (without respiratory system infections or exacerbations). Patients with exacerbated lung disease, decompensated cardiovascular disease, rheumatic diseases, neuromuscular diseases, or orthopedic diseases that prevented them from 
performing the proposed tests or affected their performance on those tests were excluded, as were those who underwent a change in medication during the study period and those who had uncontrolled arterial hypertension.

Evaluations were performed between March and September of 2012. All participants were informed of the procedures involved in the study and gave written informed consent. The study was approved by the local research ethics committee (Ruling no. 213/2012).

All participants underwent the following: anamnesis; anthropometric data collection; administration of the mMRC scale, the modified Baecke questionnaire, and the IPAQ, short version; the 6MWT; and monitoring of the number of steps/day by using a pedometer. The procedures were performed on different days, the first of which included anamnesis, anthropometric data collection, and administration of the questionnaires and the mMRC scale, as well as fitting of the pedometer for monitoring of the number of steps/day. The patients were instructed to return after three days of monitoring for pedometer data collection and for undergoing the 6MWT.

Anthropometric data (weight and height) were obtained with the use of a calibrated mechanical scale (Welmy S.A., Santa Bárbara do Oeste, Brazil) in order to calculate the BMl, which is used for the calculation of the BODE index. ${ }^{(5)}$

To assess the sensation of dyspnea, we used the validated Brazilian-Portuguese language version of the mMRC scale, which was administered as an interview. Patients were asked about the extent to which their sensation of dyspnea limits their activities of daily living and were instructed to choose only one alternative. The mMRC scale comprises five grades, characterizing the different activities that lead to the sensation of dyspnea. ${ }^{(15)}$

The 6MWT was performed along a 30-mlong by $1.5-\mathrm{m}$-wide course with markings every $2 \mathrm{~m}$, as recommended by the American Thoracic Society. ${ }^{(16)}$ For patients on home oxygen therapy, the test was supplemented with the same oxygen flow as that used at home. Predicted 6MWD for each patient was calculated by the lwama et al. equation. ${ }^{(17)}$

To determine the risk of mortality, we used the BODE index, which was calculated considering the following variables: $\mathrm{BMI}$; $\mathrm{FEV}_{1}$ (\% of predicted), ${ }^{(18)}$ mMRC score, and 6MWD. The BODE index (total score) ranges from 0 to 10 , with higher scores indicating greater disease severity. On the basis of these scores, the BODE index was calculated as a predictor of mortality, being divided into quartiles as follows: quartile 1 (0-2 points); quartile 2 (3-4 points); quartile 3 (5-6 points), and quartile 4 (7-10 points). ${ }^{(5)}$

The level of physical activity was subjectively assessed by using two questionnaires (the IPAQ, short version and the modified Baecke questionnaire), which were administered as an interview. The IPAQ, short version allows an estimate of time spent per week on different physical activities, in order to classify individuals as sedentary, irregularly active (A or B), active, or very active. ${ }^{(11)}$ For the purpose of analysis, this classification was converted to continuous values expressed as metabolic equivalent minutes per week (MET-min/wk), ${ }^{(19)}$ for each domain alone (walking activity, moderate physical activity, and vigorous physical activity) and in combination (sum of all physical activity). The modified Baecke questionnaire, validated by Pols et al., ${ }^{(13)}$ was administered to assess the patient's usual exercise capacity subjectively. 1t comprises 12 questions related to three domains: activities of daily living; sports; and leisure activities. The activities of daily living domain contain 10 questions, which are answered on a 0 to 3 scale, with 0 meaning "never does the task" and 3 meaning "always does the task". The other domains comprise open-ended questions in which patients report the time of year when they do sports and leisure activities and the amount of time they spend on these activities. For the activities of daily living domain, the final score was calculated by adding up the points assigned to each question and dividing the result by the total number of questions in that domain; for the other domains, the final score was calculated with a code that classifies the energy expenditure level of the given activity. Finally, the three domain scores were added up, and the level of physical activity of the patient was determined. ${ }^{(12)}$

The number of steps/day was quantified by a Yamax Digi-Walker SW-700 pedometer (Yamax, Tokyo, Japan), which is considered the most accurate commercially available pedometer. ${ }^{(20,21)}$ It consists of a small sensor and a mechanical counter that have the purpose of recording the movements made in response to the vertical acceleration of the body. The oscillations are computed by adding up the total number of 
accumulated movements and determine the total number of steps taken over the period assessed. (21) In our study, the equipment was positioned at the patients' waistline, at the level of the right anterosuperior iliac crest, being clipped to their belt or clothes. The volunteers were instructed not to change their habitual routines and to wear the pedometer continuously throughout the period of wakefulness for three consecutive days ${ }^{(22)}$ in order to characterize a usual week's pattern, excluding the weekend. For the analysis, we considered the mean of the values obtained on the three days, so that a single value was regarded as the level of activity of daily living. No benchmark minimum number of steps/day was provided to the participants. In addition, the patients were instructed to keep a diary to report the activities performed every one hour.

Data were analyzed with the Statistical Package for the Social Sciences, version 17.0 (SPSS Inc., Chicago, IL, USA). Normality of the data was assessed by the Shapiro-Wilk test. The patients who achieved the minimum number of 4,580 steps/day were compared with those who did not by using the Mann-Whitney test or the unpaired t-test according to the data distribution pattern. Correlations of pedometer-determined steps/ day with the scores on the IPAQ, short version and the modified Baecke questionnaire, which are subjective instruments, were tested by using Spearman's correlation coefficient. The level of statistical significance was set at $p<0.05$. The power of the test was calculated by using the Ene software, version 2.0 (GlaxoSmithKline, Madrid, Spain). To that end, we considered the standard deviation of the variable "pedometerdetermined steps/day" and a level of significance of $5 \%$, which resulted in a power of over $80 \%$.

\section{Results}

The study sample initially consisted of 38 patients, of whom 30 completed the study and 8 were excluded because of failure to complete all of the steps of the evaluations. Of the sample, 15 patients achieved more than 4,580 steps/ day ${ }^{(10)}$ and were considered to have no severe physical inactivity (SPl-group), whereas $15 \mathrm{did}$ not achieve this number and were considered to have severe physical inactivity (SPl+ group). Of those 30 patients, 6 were oxygen-dependent (3 in each group).
Table 1 shows the demographic and anthropometric characteristics, the BODE index and its components, and objective and subjective characteristics of the level of physical activity of the COPD patients in the total sample and by group.

Intergroup analysis showed that the patients had similar values for BMI, degree of airway obstruction, classification of prognosis for mortality, perception of dyspnea in activities of daily living (mMRC scale), modified Baecke questionnaire scores (total score, leisure domain score, and sports domain score), and IPAQ, short version scores (MET-min/wk of moderate and vigorous physical activity). However, the patients in the $\mathrm{SPl}+$ group were found to have significantly higher values for age and for the leisure domain score of the modified Baecke questionnaire, which means more time spent on activities that do not involve body displacement; in addition, these patients had lower functional exercise capacity and reported less time spent on walking activity and total physical activity in comparison with those in the SPI- group.

Pedometer-determined steps/day showed a weak but statistically significant correlation with the IPAQ, short version total score $(\mathrm{r}=$ 0.399; $p=0.029$ ) in the total sample of patients (Figure 1). However, no significant correlation was found between steps/day and the modified Baecke questionnaire total score $(r=-0.129 ; p=$ 0.496). In addition, steps/day showed statistically significant correlations with age $(r=-0.459$; $p=0.011)$ and 6MWD-in $m(r=0.446 ; p=$ $0.013)$ and in $\%$ of predicted $(r=0.422 ; p=$ 0.020). The correlations of steps/day with the BODE index and its components (BMl, FEV and $\mathrm{mMRC}$ ) were not statistically significant.

\section{Discussion}

The results of our study showed that, after the patients were divided into two groups, i.e., the $\mathrm{SPl}+$ and $\mathrm{SPl}-$ groups, on the basis of a minimum number of 4,580 steps/day, which is considered a strong predictor of mortality by Depew et al., ${ }^{(10)}$ there was no difference between the groups regarding the classification of severity by the BODE index or the scores on the BODE index and its components "mMRC score", "BMl", and "FEV $(\%$ of predicted)".

One possible factor that may have limited these aforementioned findings was the reduced 
Table 1 - Demographic characteristics, anthropometric characteristics, and level of physical activity of the patients studied. ${ }^{\mathrm{a}}$

\begin{tabular}{|c|c|c|c|c|}
\hline \multirow[t]{2}{*}{ Characteristic } & Total & SPl-group & $\mathrm{SPl}+$ group & \multirow[t]{2}{*}{$\mathrm{p}^{*}$} \\
\hline & $(n=30)$ & $(n=15)$ & $(n=15)$ & \\
\hline Age, years & $68 \pm 10$ & $62 \pm 8$ & $74 \pm 8$ & 0.001 \\
\hline Men/women, n/n & $23 / 7$ & $10 / 5$ & $13 / 2$ & 0.671 \\
\hline $\mathrm{BMl}, \mathrm{kg} / \mathrm{cm}^{2}$ & $24.6 \pm 4.7$ & $23.9 \pm 4.4$ & $24.3 \pm 5.2$ & 0.432 \\
\hline Steps/day & $4.227 \pm 2.075$ & $5.780 \pm 1.355$ & $2.674 \pm 1.384$ & 0.000 \\
\hline $\mathrm{FEV}_{1}, \%$ of predicted & $48.0 \pm 14.9$ & $47.1 \pm 16.1$ & $49 \pm 14.2$ & 0.732 \\
\hline 6MWD, m & $380.3 \pm 108.3$ & $434.6 \pm 95.8$ & $326.2 \pm 93.8$ & 0.004 \\
\hline 6MWD, \% of predicted & $70.1 \pm 18.7$ & $79.2 \pm 16.4$ & $60.8 \pm 16.7$ & 0.005 \\
\hline mMRC score ${ }^{b}$ & $2(0.00-2.25)$ & $2(0-3)$ & $2(0-2)$ & 0.589 \\
\hline BODE index & $3.5 \pm 1.9$ & $3.3 \pm 2.1$ & $3.7 \pm 1.7$ & 0.567 \\
\hline Quartile $^{\mathrm{b}}$ & $2(1-3)$ & $2(1-3)$ & $2(1-3)$ & 0.760 \\
\hline Quartile $1^{\mathrm{c}}$ & $10(33.3)$ & $5(33.3)$ & $5(33.3)$ & \\
\hline Quartile $2^{c}$ & $10(33.3)$ & $5(33.3)$ & $5(33.3)$ & \\
\hline Quartile 3c & $9(30.0)$ & $4(26.7)$ & $5(33.3)$ & \\
\hline Quartile $4^{c}$ & $1(3.3)$ & $1(6.7)$ & $0(0.0)$ & \\
\hline \multicolumn{5}{|l|}{$\mathrm{mBQ} \mathrm{Q}^{\mathrm{b}}$} \\
\hline Household domain & $1.1(0.6-1.7)$ & $1.3(0.3-1.9)$ & $1.0(0.6-1.5)$ & 0.466 \\
\hline Sports domain & $1.4(0.0-4.1)$ & $2.5(0.0-4.1)$ & $0.2(0.0-4.2)$ & 0.622 \\
\hline Leisure domain & $1.2(1.0-2.9)$ & $1.1(0.6-1.4)$ & $1.4(1.2-3.5)$ & 0.023 \\
\hline Total & $5.3(2.5-7.2)$ & $4.8(3.3-5.9)$ & $5.7(2.2-8.3)$ & 0.604 \\
\hline \multicolumn{5}{|l|}{ IPAQ, short version ${ }^{\mathrm{b}}$} \\
\hline MET-min/wk of W & $231.0(0.0-358.8)$ & 346.5 (82.5-528.0) & $33.0(0.0-247.5)$ & 0.005 \\
\hline MET-min/wk of MPA & $160(0-510)$ & $240(0-600)$ & $80(0-360)$ & 0.297 \\
\hline MET-min/wk of VPA & $0(0-0)$ & $0(0-0)$ & $0(0-0)$ & 0.317 \\
\hline MET-min/wk of TPA & 338.2 (153.0-979.5) & 586.5 (330.0-1.150) & $247.5(0.0-657.0)$ & 0.028 \\
\hline
\end{tabular}

SPI-: no severe physical activity; SPl+: severe physical activity; BMI: body mass index; 6MWD: six-minute walk distance; mMRC: modified Medical Research Council; IPAQ: International Physical Activity Questionnaire; BODE: (B: body mass index, 0: airflow obstruction, D: dyspnea, E: exercise capacity); mBQ; modified Baecke questionnaire; MET-min/wk of W: metabolic equivalent minutes per week of walking activity; MET-min/wk of MPA: metabolic equivalent minutes per week of moderate physical activity; MET-min/wk of VPA: metabolic equivalent minutes per week of vigorous physical

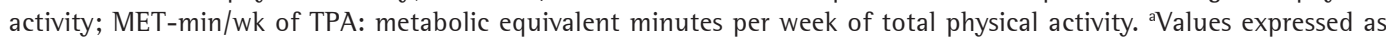
mean $\pm \mathrm{dp}$; except where otherwise indicated. ${ }^{b}$ Values expressed as median (interquartile range). 'Values expressed as $\mathrm{n}(\%) .{ }^{*}$ Mann-Whitney test or unpaired t-test.

number of patients in the last two quartiles (10 of the total sample), as well as the fact that the groups showed no differences in the classification of severity by the BODE index. One group of authors ${ }^{(23)}$ showed that level of physical activity correlates only modestly with classification of severity in COPD by the BODE index, which is more sensitive when differences in the level of daily physical activity are analyzed between patients with mild to moderate disease and patients with severe to very severe disease. Although quartile 1 and quartile 2 patients show a decrease in the level of physical activity, the decrease is subtle, whereas in quartile 3 and quartile 4 patients, this decrease is more marked.

When the two groups were compared for age, we found that there was a significant difference and correlation, age being greater in the $\mathrm{SPl}+$ group than in the $\mathrm{SPI}-$, which shows that, as age increases, there is a trend toward a decrease in the number of steps/day. In a descriptive meta-analysis, ${ }^{(24)}$ it was found that, in groups with a mean age over 65 years, the number of steps/day is significantly lower; one possible explanation is that, as age increases, gait velocity decreases, which does not allow the pedometer to record an accurate step count. However, in our study, we believe that, since the groups showed a significant difference also in the domain "MET-min/wk of walking activity" and in 6MWD, the difference between the two groups occurred because of a decrease in walking activity among the older patients, rather than because of a possible limitation of pedometers. 


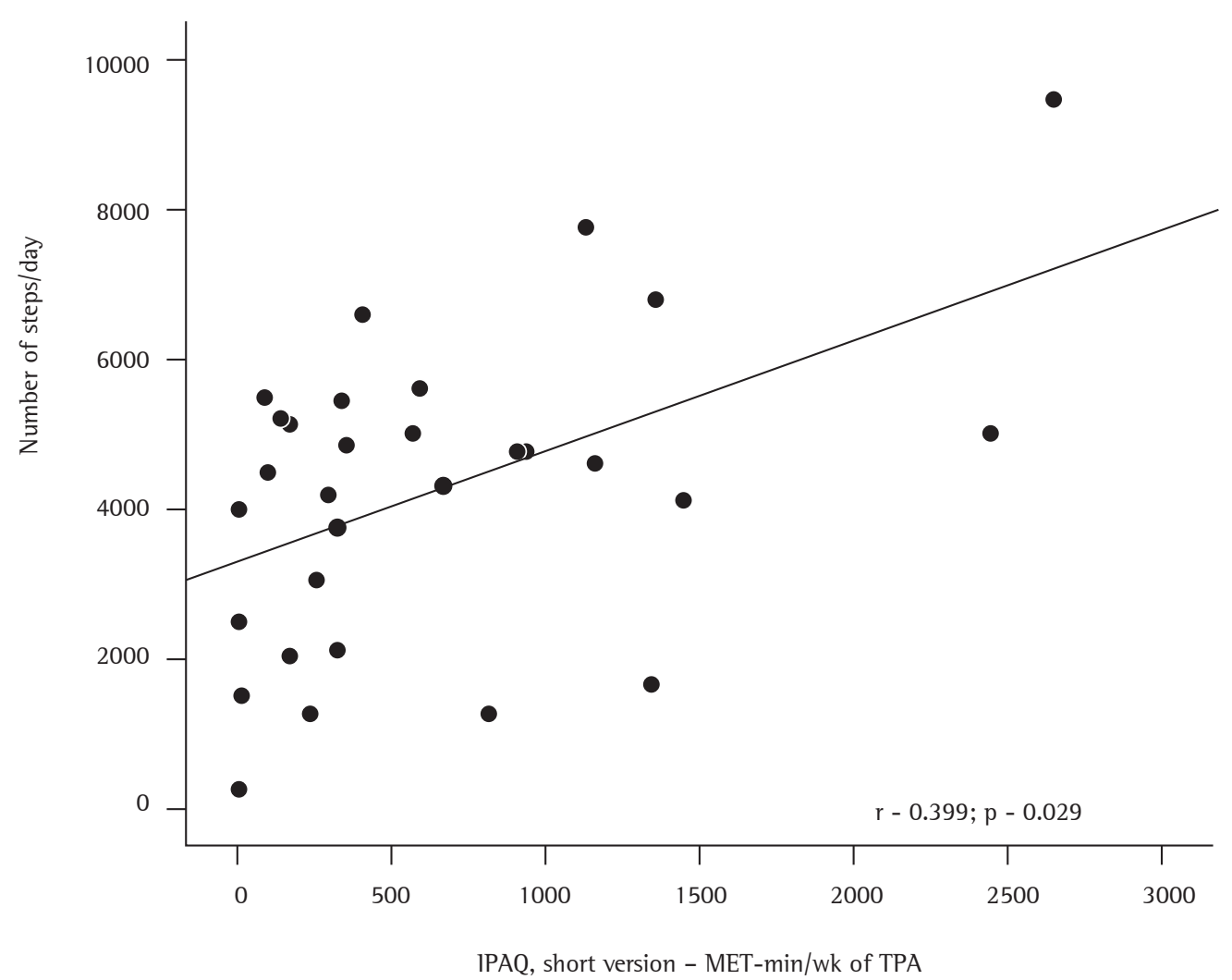

Figure 1 - Correlation between pedometer-determined steps/day and the International Physical Activity Questionnaire (IPAQ), short version score for the domain "metabolic equivalent minutes per week of total physical activity" (MET-min/wk of TPA).

Pitta et al. ${ }^{(25)}$ found that daily walking time was weakly correlated with $\mathrm{FEV}_{1}(r=0.28)$ and BMI $(r=-0.08)$ but strongly correlated with the 6MWT ( $r=0.76)$. In our study, we found no significant differences or correlations between the groups when we analyzed FEV $1 \%$ of predicted), which shows that impairment related to airflow obstruction was not associated with a lower level of daily living activity. Oga et al. ${ }^{(26)}$ stated that patient activity can be limited by an increased degree of pulmonary obstruction; however, those authors reported that $\mathrm{FEV}_{1}$ is not beneficially influenced by physical activity. As in the study by Pitta et al., ${ }^{(25)}$ we found a relationship between pedometer-measured physical activity and 6MWD, with the group with a higher level of physical activity having greater functional capacity (as assessed by the 6MWT) than the group with a lower level of physical activity.

Regarding the differences found in the leisure domain of the modified Baecke questionnaire, the results show that the patients in the $\mathrm{SPl}+$ group, who took less than 4,580 steps/day, spent more time on these activities. The fact that most of the activities reported within this domain were reading magazines, watching $\mathrm{TV}$, performing manual tasks, etc, explains why the patients in the $\mathrm{SPI}+$ group took less than 4,580 steps/ day on average, because these activities do not involve body displacements, which are recorded by the pedometer.

Regarding the correlation of pedometerdetermined steps/day with the scores on the physical activity questionnaires, which are subjective instruments, we found that only the IPAQ, short version score showed a significant but weak correlation $(r=0.399)$ with steps/ day. A systematic review ${ }^{(27)}$ reported that most validation studies found only weak correlations between IPAQ scores and objective measures of physical activity. In the present study, the modified Baecke questionnaire score showed no correlation with pedometer-determined steps/ day. Unlike in our study, Mazo et al. ${ }^{(28)}$ found weak to moderate concurrent validity between the modified Baecke questionnaire score and 
pedometer-determined steps/day in a group of elderly women.

Limitations of our study include the fact that the sample was selected by convenience, not being representative of the general population, and that the number of patients in each BODE index quartile was not similar, there being only 1 patient in quartile 4 . In addition, three days of pedometer monitoring, despite references in the literature, might have underestimated or overestimated the step counts; the number of steps might also have been underestimated by the fact that COPD patients tend to have slow gait velocity, which impacts on the detection of oscillations during gait, and this can lead to inaccurate step counts.

Therefore, the present study showed that the cut-off of 4,580 steps/day ${ }^{(10)}$ was not sensitive enough to identify differences between the groups in our sample when compared with established predictors of mortality. Of the scores on the two questionnaires for physical activity assessment, the IPAQ, short version score correlated better with pedometer-measured physical activity.

\section{References}

1. National Heart, Lung, and Blood Institute. Morbidity and Mortality: Chartbook on Cardiovascular, Lung, and Blood Diseases. Bethesda: National Heart, Lung, and Blood Institute; 2009.

2. World Health Organization. World Health Statistics 2012. Geneva: World Health Organization; 2012.

3. Global Initiative for Chronic Obstructive Lung Disease [homepage on the Internet]. Bethesda: Global Initiative for Chronic Obstructive Lung Disease. [cited 2013 Jan 10]. Global strategy for the diagnosis, management, and prevention of chronic obstructive pulmonary disease Revised 2011. [Adobe Acrobat document, 80p.]. Available from: http://www.goldcopd.org/uploads/users/files/ GOLD_Report_2011_Feb21.pdf

4. Polkey Ml, Moxham J. Attacking the disease spiral in chronic obstructive pulmonary disease. Clin Med. 2006;6(2):190-6. http://dx.doi.org/10.7861/ clinmedicine.6-2-190

5. Celli BR, Cote CG, Marin JM, Casanova C, Montes de Oca M, Mendez RA. The body-mass index, airflow obstruction, dyspnea, and exercise capacity index in chronic obstructive pulmonary disease. N Engl J Med. 2004;350(10):1005-12. http://dx.doi.org/10.1056/ NEJMoa021322 PMid:14999112

6. Garcia-Aymerich J, Lange P, Benet M, Schnohr P, Antó JM. Regular physical activity reduces hospital admission and mortality in chronic obstructive pulmonary disease: a population based cohort study. Thorax. 2006;61(9):772-8. http://dx.doi.org/10.1136/thx.2006.060145 PMid:16738033 PMCid:PMC2117100

7. Yohannes AM, Baldwin RC, Connolly M. Mortality predictors in disabling chronic obstructive pulmonary disease in old age. Age Ageing. 2002;31(2):137-40. http://dx.doi. org/10.1093/ageing/31.2.137 PMid:11937477

8. Waschki B, Kirsten A, Holz O, Müller KC, Meyer T, Watz $\mathrm{H}$, et al. Physical activity is the strongest predictor of all-cause mortality in patients with COPD: a prospective cohort study. Chest. 2011;140(2):331-42. http://dx.doi. org/10.1378/chest.10-2521 PMid:21273294

9. Watz H, Waschki B, Boehme C, Claussen M, Meyer T, Magnussen $\mathrm{H}$. Extrapulmonary effects of chronic obstructive pulmonary disease on physical activity: a cross-sectional study. Am J Respir Crit Care Med. 2008;177(7):74351. http://dx.doi.org/10.1164/rccm.200707-10110C PMid:18048807

10. Depew ZS, Novotny PJ, Benzo RP. How many steps are enough to avoid severe physical inactivity in patients with chronic obstructive pulmonary disease? Respirology. 2012;17(6):1026-7. http://dx.doi.org/10.1111/j.14401843.2012.02207.x PMid:22672739 PMCid:PMC3409325

11. Matsudo S, Araujo T, Marsudo V, Andrade D, Andrade E, Oliveira LC, et al. Questionário Internacional de Atividade Física (IPAQ): Estudo de validade e reprodutibilidade no Brasil. Rev Bras Ativ Fis Saude. 2001;6(2):5-18.

12. Florindo AA, Latorre MR. Validação e reprodutibilidade do questionário de Baecke de avaliação da atividade física habitual em homens adultos. Rev Bras Med Esportes. 2003;9(3):121-8.

13. Pols MA, Peeters PH, Bueno-De-Mesquita HB, Ocké MC, Wentink CA, Kemper HC, et al. Validity and repeatability of a modified Baecke questionnaire on physical activity. Int J Epidemiol. 1995;24(2):381-8. http://dx.doi.org/10.1093/ ije/24.2.381 PMid:7635600

14. Rabacow FM, Gomes MA, Marques P, Benedetti TR. Questionários de medidas de atividade física em idosos. Rev Bras Cineantropom Desempenho Hum. 2006;8(4):99-106.

15. Bestall JC, Paul EA, Garrod R, Garnham R, Jones PW, Wedzicha JA. Usefulness of the Medical Research Council (MRC) dyspnoea scale as a measure of disability in patients with chronic obstructive pulmonary disease. Thorax. 1999;54(7):581-6. http://dx.doi.org/10.1136/ thx.54.7.581 PMid:10377201 PMCid:PMC1745516

16. ATS Committee on Proficiency Standards for Clinical Pulmonary Function Laboratories. ATS statement: guidelines for the six-minute walk test. Am J Respir Crit Care Med. 2002;166(1):111-7. http://dx.doi.org/10.1164/ ajrccm.166.1.at1102 PMid:12091180

17. Iwama AM, Andrade GN, Shima P, Tanni SE, Godoy 1, Dourado VZ. The six-minute walk test and body weightwalk distance product in healthy Brazilian subjects. Braz J Med Biol Res. 2009;42(11):1080-5. Erratum in: Braz J Med Biol Res. 2010;43(3):324. http://dx.doi.org/10.1590/ S0100-879X2009005000032 PMid:19802464

18. Knudson RJ, Slatin RC, Lebowitz MD, Burrows B. The maximal expiratory flow-volume curve. Normal standards, variability, and effects of age. Am Rev Respir Dis. 1976;113(5):587-600. PMid:1267262

19. Craig CL, Marshall AL, Sjöström M, Bauman AE, Booth ML, Ainsworth BE, et al. International physical activity questionnaire: 12-country reliability and validity. Med Sci Sports Exerc. 2003;35(8):1381-95. http:// dx.doi.org/10.1249/01.MSS.0000078924.61453.FB PMid:12900694

20. Welk GJ, Differding JA, Thompson RW, Blair SN, Dziura J, Hart P. The utility of the Digi-walker step counter to assess daily physical activity patterns. Med Sci 
Sports Exerc. 2000;32(9 Suppl):S481-8. http://dx.doi. org/10.1097/00005768-200009001-00007 PMid:10993418

21. Schneider PL, Crouter S, Bassett DR. Pedometer measures of free-living physical activity: comparison of 13 models. Med Sci Sports Exerc. 2004;36(2):331-5. http://dx.doi.org/10.1249/01.MSS.0000113486.60548. E9 PMid:14767259

22. Trost SG, Mclver KL, Pate RR. Conducting accelerometerbased activity assessments in field-based research. Med Sci Sports Exerc. 2005;37(11 Suppl):S531-43. http:// dx.doi.org/10.1249/01.mss.0000185657.86065.98 PMid:16294116

23. Mantoani LC, Hernandes NA, Guimarães MM, Vitorasso RL, Probst VS, Pitta F. Does the BODE index reflect the level of physical activity in daily life in patients with COPD? Rev Bras Fisioter. 2011;15(2):131-7. http://dx.doi. org/10.1590/S1413-35552011000200008 PMid:21789363

24. Bohannon RW. Number of pedometer-assessed steps taken per day by adults: a descriptive meta-analysis. Phys Ther. 2007;87(12):1642-50. http://dx.doi.org/10.2522/ ptj.20060037 PMid:17911274
25. Pitta F, Troosters T, Spruit MA, Probst VS, Decramer M, Gosselink R. Characteristics of physical activities in daily life in chronic obstructive pulmonary disease. Am J Respir Crit Care Med. 2005;171(9):972-7. http:// dx.doi.org/10.1164/rccm.200407-8550C PMid:15665324

26. Oga T, Nishimura K, Tsukino M, Sato S, Hajiro T. Analysis of the factors related to mortality in chronic obstructive pulmonary disease: role of exercise capacity and health status. Am J Respir Crit Care Med. 2003;167(4):544-9. http://dx.doi.org/10.1164/rccm.200206-5830C PMid:12446268

27. Lee PH, Macfarlane DJ, Lam TH, Stewart SM. Validity of the International Physical Activity Questionnaire Short Form (IPAQ-SF): a systematic review. Int J Behav Nutr Phys Act. 2011;8:115. http://dx.doi.org/10.1186/14795868-8-115 PMid:22018588 PMCid:PMC3214824

28. Mazo GZ, Mota J, Benedetti TB, Barros MV. Validade concorrente e reprodutibilidade: teste-reteste do Questionário de Baecke modificado para idosos. Rev Bras Ativ Fis Saude. 2001;6(1):5-11.

\section{About the authors}

\section{Samantha Maria Nyssen}

Physical Therapist. Laboratory of Spirometry and Respiratory Therapy, Department of Physical Therapy, Universidade Federal de São Carlos - UFSCar, Federal University of São Carlos - São Carlos, Brazil.

\section{Júlia Gianjoppe dos Santos}

Doctoral Student. Department of Physical Therapy, Universidade Federal de São Carlos - UFSCar, Federal University of São Carlos - São Carlos, Brazil.

\section{Marina Sallum Barusso}

Master's Student. Department of Physical Therapy, Universidade Federal de São Carlos - UFSCar, Federal University of São Carlos - São Carlos, Brazil.

\section{Antônio Delfino de Oliveira Junior}

Physician. Department of Physical Therapy, Universidade Federal de São Carlos - UFSCar, Federal University of São Carlos - São Carlos, Brazil.

\section{Valéria Amorim Pires Di Lorenzo}

Associate Professor. Department of Physical Therapy, Universidade Federal de São Carlos - UFSCar, Federal University of São Carlos - São Carlos, Brazil.

\section{Mauricio Jamami}

Associate Professor. Department of Physical Therapy, Universidade Federal de São Carlos - UFSCar, Federal University of São Carlos - São Carlos, Brazil. 